\title{
Kerjasama Guru dan Supervisor dalam Meningkatkan Mutu Pembelajaran di SMP Ar-Rohmah Boarding School Pesantren Hidayatullah Dau Malang
}

\author{
Muhammad Rouf \\ Sekolah Tinggi Agama Islam Al Hikmah Tuban \\ Email: rouf.idaman@gmail.com \\ Nur Ajeng Maftukhah \\ Sekolah Tinggi Ilmu Tarbiyah Makhdum Ibrahim Tuban \\ Email: ajengnurm@gmail.com
}

\begin{abstract}
Abstrak
Kualitas pembelajaran yang baik hanya akan bisa tercapai apabila para guru yang ada di dalamnya dapat menciptakan pembelajaran yang berkualitas. Dalam hal ini peran yang sangat besar ada pada supervisor pendidikan, yaitu kepala sekolah sebagai supervisor internal dan pengawas sekolah sebagai supervisor eksternal. Fokus penelitian dalam penelitian ini adalah implementasi tugas pokok dan fungsi supervisor dalam melakukan peningkatan pembelajaran, implementasi tugas pokok dan fungsi guru dalam melakukan peningkatan pembelajaran, dan kerja sama antara supervisor dan guru dalam meningkatkan pembelajaran siswa di SMP Boarding School Pesantren Hidayatullah Dau Malang. Penelitian ini menggunakan jenis penelitian kualitatif deskriptif. Adapun teknik pengumpulan data meliputi pengamatan terlibat, wawancara mendalam dan dokumentasi. Sedangkan teknik analisis data menggunakan SWOT (Strength, Weaknesses, Opportunities, Threats) pada setiap fokus penelitian yang telah dirumuskan. Dalam penelitian ini, ada tiga temuan penting sebagai hasil analisis. Pertama, supervisor kurang maksimal dalam memberikan pembinaan secara aktif kepada guru di SMP Ar-Rohmah ini. Kedua, Mayoritas guru di SMP Ar-rohmah ini melakukan pembelajaran dengan baik dan mematuhi semua SOP (Standard Operating Procedure) yang telah ditetapkan di sekolah. Walaupun penguasaan metode pembelajaran kurang, mereka sangat antusias untuk belajar berinovasi dalam melakukan pembelajaran di kelas. Ketiga, kerja sama antara guru dan pengawas lebih banyak dilakukan di dalam sekolah yang diinisiasi oleh sekolah sendiri. SMP Ar-Rohmah lebih berperan aktif dari pada pembinaan yang dilakukan oleh supervisor eksternal.
\end{abstract}

Kata kunci: Kerjasama Guru; supervisor, mutu Pembelajaran. 


\section{Pendahuluan}

Menelusuri krisis pendidikan nasional yang kurang bermutu, sukar kita menetapkan salah satu penyebabnya yang pasti, karena akan seperti mengurai benang kusut atau mencari jarum dalam tumpukan jerami. Sehingga pastinya penelusuran akan sampai pada jantung kegiatan di sekolah sebagai kata kuncinya yaitu penyelenggaraan belajar mengajar yang ditangani guru harus diperhatikan, sebab di sinilah dapur kegiatan belajar berada. Usaha yang telah dilakukan pemerintah mengawasi jalannya pendidikan untuk mendongkrak mutu bila ditindaklanjuti dengan pembinaan gurunya, tidak tidak akan berdampak nyata pada kegiatan layanan di kelas. Kegiatan pembinaan guru merupakan bagian yang tidak mungkin dipisahkan dalam setiap usaha peningkatan mutu pembelajaran.

Kajian yang dilakukan oleh Depdiknas, Bappenas dan Bank Dunia menemukan bahwa guru merupakan kunci penting dalam keberhasilan memperbaiki mutu pendidikan. Hasil kajian itu mengemukakan; "guru merupakan titik sentral dalam usaha mereformasi pendidikan, dan mereka menjadi kunci keberhasilan setiap usaha peningkatan mutu pendidikan. Apapun namanya, apakah itu pembaruan kurikulum, pengembangan metodemetode mengajar, peningkatan pelayanan belajar, menyediakan buku teks, hanya akan berarti apabila melibatkan guru". ${ }^{1}$

Berdasarkan hasil kajian di atas, maka kualitas atau mutu pembelajaran menjadi sangat penting di sini. Kualitas pembelajaran yang baik hanya akan bisa tercapai apabila para guru yang ada di dalamnya dapat menciptakan pembelajaran yang baik pula. Dalam hal ini peran sangat besar adalah ada pada supervisor pendidikan, yaitu kepala sekolah yang ada di internal lembaga pendidikan, ataupun supervisor eksternal yang berasal dari luar lembaga pendidikan yang biasa disebut "pengawas" sebagai tugas dinas dari Kemendiknas ataupun Kemenag RI yang berada di wilayah tanggung jawabnya masing-masing.

Dalam rangka otonomi sekolah, kepala sekolah mempunyai kewenangan yang besar dalam membuat kebijakan tingkat sekolah, melaksanakan dan mengawasinya, supaya sekolah yang dipimpinnya semakin memiliki kemampuan untuk mengembangkan potensi diri dan lingkungannya. Kepala sekolah sebagai penanggung jawab pendidikan, sekarang memiliki kewenangan dan keleluasaan dalam; mengembangkan program, mengelola dan mengawasinya, memiliki kekuasaan dalam mengatur segenap sumber daya yang dimilikinya, yang dapat digalinya supaya terjadi peningkatan mutu dan produktifitas yang signifikan dalam memberikan layanan belajar bermutu melalui guru-guru profesional dan

\footnotetext{
${ }^{1}$ Cicih Sutarsih et al., "Supervisi Pendidikan", Tim Dosen Administrasi Pendidikan UPI,
} Manajemen Pendidikan (Bandung: Alfabeta, 2008), 311. 
kooperatif. ${ }^{2}$ Seharusnya otonomi ini bisa dijadikan peluang bagi kepala sekolah untuk memaksimalkan kreatifitasnya dalam rangka menghasilkan pelayanan pembelajaran yang berkualitas melalui pembinaan para karyawan sekolah dan lebih penting lagi adalah bagi para guru yang secara langsung bertanggung jawab pada proses pembelajaran di kelas. Segala proses manajerial maupun leadership kepala sekolah ujung-ujungnya tiada lain adalah untuk dapat menghasilkan pembelajaran yang baik bagi para siswa dengan guru sebagai ujung tombaknya.

Permasalahan yang terjadi di lapangan adalah peran serta supervisor eksternal. Supervisor eksternal di sini adalah petugas khusus yang ditunjuk oleh Kasi PENMA (Pendidikan Madrasah) di lingkungan Kemenag maupun petugas yang telah ditunjuk oleh Diknas di tiap Kabupaten/Kota. Banyak supervisor yang tidak melaksanakan tugas dan tanggung jawabnya dengan baik. Sebagaimana fungsi supervisor pendidikan yang tugasnya adalah melakukan pengawasan pendidikan baik secara manajerial ataupun akademik. Pengawasan manajerial merupakan pengawasan yang menitikberatkan pada pelaksanaan administrasi dan manajemen sekolah, sedangkan pengawasan akademik lebih spesifik pada pengawasan implementasi pembelajaran para guru dalam proses belajar mengajar.

SMP Ar-Rohmah Boarding School yang terletak di kompleks Pesantren Putra Hidayatullah Dau Malang ini adalah sekolah swasta yang berada dalam yayasan "Ar-Rohmah" milik sebuah Ormas (Organisasi Masyarakat) Islam Hidayatullah. Hidayatullah adalah salah satu dari sekian banyak Ormas Islam yang ada di Indonesia, konsentrasi gerakan yang dilakukannya adalah dakwah, sosial dan pendidikan. Organisasi ini memiliki kepengurusan dan keanggotaan secara nasional, yang di dalamnya terdapat pengurus pusat yang ada di Ibu Kota, pengurus wilayah yang berada di tiap Propinsi dan pengurus di tingkat cabang atau Kabupaten. Penulis banyak melihat di beberapa daerah, bahwa yang menarik dan sangat massif dilakukan Ormas ini adalah komitmen para pengurusnya untuk mengembangkan lembaga pendidikan sebanyak-banyaknya. Lembaga pendidikan yang dikembangkan adalah mulai dari Taman Kanak-Kanak (TK), Sekolah Dasar (SD), Sekolah Menengah Pertama (SMP) dan Sekolah Menengah Atas (SMA). Penulis mengamati hampir di tiap Kabupaten Hidayatullah memiliki banyak sekali lembaga pendidikan yang berbasiskan Islam atau lebih tepatnya pesantren. Begitu pula dengan SMP Ar-Rohmah Boarding School Dau Malang ini, merupakan salah satu unit pendidikan di Ormas Hidayatullah yang berbasis pesantren.

Penelitian ini dilakukan karena ada hal yang menarik di SMP ArRohmah Boarding School Dau Malang ini. Setelah melakukan penjajakan,

${ }^{2}$ Ibid., 312.

El-Banat Vol. 9. No.1, Januari-Juni 201937 
penulis mendapati ada beberapa hal yang unik di sini. Pertama adalah sekolah ini berada di kompleks pesantren putra. Jadi, semua siswa di sini adalah laki-laki dan gurunya pun diharuskan laki-laki. Sekolah sangat melarang adanya interaksi yang berlebih antara laki-laki dan perempuan yang bukan muhrim di kompleks ini. Kedua, bahwa banyak para guru yang direkrut untuk mengajar di sini tidak diharuskan memiliki ijazah pendidikan (sarjana pendidikan), akan tetapi keahlian keilmuan murni sesuai bidang yang akan diajarkannya. Ketiga, yang merupakan hal penting di sini, adalah sekolah ini memiliki Standar Operational Procedure (SOP) yang begitu sistematis melebihi sekolah-sekolah negeri milik pemerintah. SOP itu, walaupun tidak terlalu berat akan tetapi sangat banyak dan bermacammacam. Semua itu dibuat, tiada lain adalah dalam rangka meningkatkan profesionalitas lembaga di semua sektor. Keempat, adanya supervisor atau pengawas dari Diknas ataupun Kemenag yang kurang berpengaruh secara signifikan di sekolah ini. Menurut keterangan yang didapatkan, hal itu terjadi karena terbatasnya tenaga supervisor untuk menangani semua sekolah di wilayah yang menjadi tanggung jawabnya. Jadi, ada ketidakseimbangan antara rasio jumlah pengawas dengan jumlah sekolah yang ditangani.

Penelitian ini dilakukan berdasarkan penjajakan awal yang dilakukan penulis dengan mengetahui beberapa keunikan di atas. Untuk itu, melihat paparan ke-khasan SMP ini, maka penulis menekankan penelitian ini pada judul Kerja Sama antara Supervisor dengan Guru Meningkatkan Pembelajaran di SMP Ar-Rohmah "Boarding School" Pesantren Hidayatullah Dau Malang. Dengan tiga fokus penelitian, yaitu implementasi tugas pokok dan fungsi supervisor dalam melakukan peningkatan pembelajaran, implementasi tugas pokok dan fungsi guru dalam melakukan peningkatan pembelajaran, dan kerja sama antara supervisor dan guru dalam meningkatkan pembelajaran siswa.

Peneliti menggunakan jenis penelitian kualitatif deskriptif. Di mana penelitian ini mempunyai ciri khas yang terletak pada tujuannya, yakni mendeskripsikan tentang segala sesuatu yang berkaitan dengan judul penelitian. Jadi, penelitian ini bertujuan untuk memahami fenomena yang terjadi secara holistik dan dengan cara mendeskripsikan dalam bentuk katakata dan bahasa pada suatu konteks khusus alamiah dan dengan memanfaatkan berbagai metode ilmiah. ${ }^{3}$ Penelitian dilakukan di SMP ArRohmah "Boarding School" Pesantren Hidayatullah Malang yang tepatnya berada di Jl. Raya Apel 61 Sumbersekar Dau Malang Jawa Timur.

Sumber data dalam penelitian ini terdiri dari data primer dan data sekunder. Data primer adalah data yang bersifat langsung di kumpulkan oleh

\footnotetext{
${ }^{3}$ Lexy J. Moeloeng, Metodologi Penelitian Kualitatif (Bandung: Remaja Rosdakarya, 2007),
} 6. 
peneliti dari sumber pertama. ${ }^{4}$ Kepala SMP Ar-Rohmah atas nama Bapak Syarif Hidayatullah, S.Sos dan Waka Kurikulum atas nama Bapak Suwanto, S.Pd. dan Beberapa guru pendidik di SMP Ar-Rohmah ini. Sedangkan data sekunder adalah data yang biasanya telah tersusun dalam bentuk dokumendokumen yang sudah ada. ${ }^{5}$ Dalam hal ini data di gali dengan melihat datadata dokumen di SMP Ar-Rohmah "Boarding School" Dau Malang yang berkenaan dengan SOP (Standar Operation Procedure) di SMP ini karena merupakan instrumen supervisi yang dilakukan oleh Kepala Sekolah, serta dokumen supervisi pembelajaran yang dipakai oleh para supervisor eksternal.

Adapun teknik pengumpulan data meliputi pengamatan terlibat, ${ }^{6}$ wawancara mendalam ${ }^{7}$ dan dokumentasi. ${ }^{8}$ Peneliti terjun langsung mengikuti beberapa kegiatan belajar di SMP Ar-Rohmah Dau Malang ini sampai didapatkan informasi mengenai apa saja bentuk kerja sama antara pengawas dan guru di SMP Ar-Rohmah. Teknik yang kedua, penulis melakukan wawancara kepada kepala sekolah selaku supervisor internal, Waka kurikulum dan guru SMP Ar-Rohmah Dau Malang dan guru SMP ArRohmah secara mendalam dan intensif. Sedangkan teknik ketiga, penulis mengumpulkan data-data terkait dengan profil sekolah, perangkat supervisi pendidikan dan dokumen-dokumen laporan prestasi guru SMP Ar-Rohmah Dau Malang.

Hasil wawancara yang diperoleh dari satu sumber dibandingkan dengan sumber yang lain sampai ditemukan titik jenuh dimana tidak ada perbedaan informasi. Kemudian dalam menganalisis semua data yang diperoleh, penulis menggunakan analisis SWOT (Strength, Weaknesses, Opportunities, Threats) di setiap fokus penelitian yang telah dirumuskan.

\footnotetext{
${ }^{4}$ Sumardi Suryabrata, Metodologi Penelitian. (Jakarta: Raja Grafindo, 1998), 84.

5 Ibid., 84.

${ }^{6}$ Menurut Robert Bogdan dan J. Steven Taylor, pengamatan terlibat atau observasi partisipasi dipakai untuk menunjuk kepada penelitian (riset) yang dicirikan adanya interaksi sosial yang intensif antara sang peneliti dengan masyarakat yang diteliti di dalam sebuah milleu (lingkungan) masyarakat yang diteliti. Lihat Robert C. Bogdan et al., Kualitatif Dasar-dasar Penelitian, terj. A. Khozin Afandi (Surabaya: Usaha Nasional, 1993), 31.

${ }^{7}$ Menurut Rulam Ahmadi wawancara adalah cara yang utama dilakukan oleh ahli peneliti kualitatif untuk memahami persepsi, perasaan dan pengetahuan orang-orang adalah wawancara mendalam dan intensif. Yang dimaksud dengan wawancara mendalam, mendetail atau intensif adalah upaya menemukan pengalaman-pengalaman informan dari topik tertentu atau situasi spesifik yang dikaji. Oleh karena itu, dalam melaksanakan wawancara untuk mencari data digunakan pertanyaan-pertanyaan yang memerlukan jawaban berupa informasi. Lihat Rulam Ahmadi, Memahami Metodologi Penelitian Kualitatif (Malang: UM Press 2005), 71.

${ }^{8}$ Metode dokumentasi adalah metode yang digunakan untuk menelusuri data historis. Dengan demikian, dalam penelitian sejarah, bahan dokumenter memegang peranan yang sangat penting. Lihat M. Burhan Bungin, Penelitian Kualitatif (Jakarta: Kencana, 2007), 122.
}

El-Banat Vol. 9. No.1, Januari-Juni 201939 


\section{Supervisi Pendidikan}

Istilah supervisi pendidikan dibangun dari dua kata, yaitu supervisi dan pendidikan. Supervisi adalah istilah yang relatif baru dikenal di dunia pendidikan di Indonesia, karena itu perlu uraian secara lengkap tentang pengertiannya, yang akan dilihat dari dua sudut pandang, yaitu dari sudut etimologis dan terminologis. Secara etimologis, kata supervisi berasal dari bahasa Inggris, yaitu supervision, artinya adalah "pengawasan". ${ }^{9}$ Dalam kamus Oxford, kata supervisi memiliki padanan kata supervise yang artinya be in charge of and make sure everything is done correctly (bertanggung jawab dan memastikan semuanya dilakukan dengan benar). ${ }^{10}$

Secara terminologis, banyak sekali pengertian yang dikemukakan oleh para pakar. Seperti yang dipaparkan Sahertian, pada mulanya diterapkan konsep supervisi tradisional yang disebut snooper vision, yaitu tugas memata-matai untuk menemukan kesalahan. Konsep seperti ini menyebabkan guru-guru menjadi takut dan mereka bekerja dengan tidak baik karena takut dipersalahkan. Kemudian berkembang ke dalam supervisi yang bersifat ilmiah, yaitu sistematis (dilaksanakan secara teratur), obyektif (data berdasarkan observasi nyata) dan menggunakan alat pencatat yang dapat memberikan informasi terhadap proses pembelajaran di kelas. Semakin maju hasil-hasil penelitian di bidang penelitian telah membantu berubahnya berbagai pendekatan dalam supervisi pendidikan. ${ }^{11}$ Untuk memperoleh pemahaman yang utuh terhadap supervisi, perlu kiranya dipaparkan beberapa pengertian supervisi pendidikan dari para pakar, sebelum nantinya ditarik pengertian umum dari beberapa pengertian itu. Seperti yang dikutip Sahertian, Menurut Mc Merney, supervisi adalah usaha untuk menstimulasi, mengkoordinasi dan membimbing secara kontinu pertumbuhan guru-guru di sekolah baik secara individual maupun secara kolektif agar lebih mengerti dan lebih efektif dalam mewujudkan seluruh fungsi pengajaran. ${ }^{12}$

Pengertian lain dikeluarkan oleh Kimball Wiles yang menggagas konsep supervisi modern, menurutnya; "supervision is assistance in the development of a better teaching-lerning situation". Artinya, bahwa layanan supervisi meliputi keseluruhan situasi belajar mengajar (goal, material, method, teacher, student, and environment). Dengan demikian, layanan

\footnotetext{
9 John M. Enchols et al., Kamus Inggris Indonesia; An English-Indonesian Dictionary, (Jakarta: Gramedia, 1996), 596.

${ }^{10}$ Victoria Bull (ed.), Oxford; Learner's Pocket Dictionary (New York: Oxford University Press, 2008), 446.

11 Piet A. Sahertian, Konsep Dasar \& Teknik Supervisi Pendidikan; Dalam Rangka Pengembangan SumberDaya Manusia (Jakarta: Rineka Cipta, 2000), 16-17.

${ }^{12}$ Sahertian, Konsep Dasar, 17.
} 
supervisi mencakup seluruh aspek dari penyelenggaraan pendidikan dan pengajaran di sekolah. ${ }^{13}$

Pengertian yang lain disampaikan oleh Made Pidarta, menurutnya supervisi pendidikan adalah kegiatan membina para pendidik dalam mengembangkan proses pembelajaran, termasuk segala unsur penunjangnya. ${ }^{14}$ Dalam bukunya yang berjudul "Supervisi Pendidikan Kontekstual", Made Pidarta menawarkan konsep supervisi pendidikan yang kontekstual, yaitu supervisi yang berorientasi kepada sistem pendidikan desentralisasi yang sangat diwarnai oleh konteks pendidikan itu sendiri. Konteks pendidikan di sini adalah apa yang cocok diajarkan dan dipelajari oleh siswa di daerah itu serta kecakapan hidup yang dibutuhkan di daerah itu. ${ }^{15}$

Kemudian, Badan Kajian dan pengembangan Pendidikan dan Kebudayaan mendefinisikan supervisi pendidikan sebagai segala usaha yang memberikan kesempatan kepada guru untuk berkembang secara profesional, sehingga mereka lebih mampu lagi dalam melaksanakan tugas pokoknya, yaitu memperbaiki dan menyempurnakan proses belajar mengajar. ${ }^{16}$

Dari beberapa pengertian di atas, kiranya dapat dimengerti bahwa supervisi pendidikan adalah suatu kegiatan pemberian bantuan yang berupa pembinaan, bimbingan dan arahan yang diberikan oleh pengawas (kepala sekolah dan penilik sekolah atau pembina lainnya) kepada para guru dan personalia sekolah untuk dapat meningkatkan kualitas proses mutu hasil belajar mengajar. Jadi, secara umum supervisi pendidikan itu meliputi seluruh kegiatan pengawasan pada aktifitas pembelajaran atau kegiatan akademik dan pada aspek-aspek administrasi yang semuanya bermuara pada peningkatan pembelajaran bagi para siswa.

\section{Kualifikasi dan Kompetensi Pengawas Sekolah}

Pengawas sekolah di kabupaten/kota adalah pegawai negeri sipil yang diberi tugas, tanggung jawab dan wewenang oleh bupati atau walikota melakukan pengawasan di sekolah. Untuk mengkoordinasikan kegiatan pengawas, oleh para pengawas diangkat koordinator pengawas (Korwas) dengan tugas membagi para pengawas atas wilayah sesuai luasnya kabupaten/kota tersebut. ${ }^{17}$ Syaiful Sagala secara jelas memberikan paparannya, bahwa supervisor pendidikan haruslah benar-benar orang yang memahami betul seluk beluk dunia pendidikan. Disebutkannya, bahwa

\footnotetext{
${ }^{13}$ Dalam Sri Banun Muslim, Supervisi Pendidikan Meningkatkan Kualitas Profesionalisme Guru (Bandung: Alfabeta, 2009), 38.

${ }^{14}$ Made Pidarta, Supervisi Pendidikan Kontekstual (Jakarta: Rineka Cipta, 2009), 2.

${ }^{15}$ Ibid.

${ }^{16}$ Sutarsih et al., Supervisi Pendidikan, 313.

17 Syaiful Sagala, Supervisi Pembelajaran dalam Profesi Pendidikan (Bandung: Alfabeta, 2010), 154.
} 
menjadi seorang supervisor haruslah memiliki kualifikasi yang mumpuni dan kompetensi yang meliputi kompetensi manajerial dan kompetensi akademik.

\section{Kualifikasi Pengawas Sekolah}

Kualifikasi pengawas pendidikan pengawas sekolah adalah persyaratan minimal mengenai tingkat pendidikan formal dan keahlian/keilmuan, pangkat/golongan, jabatan, pengalaman kerja dan usia yang harus dipenuhi. Jadi, kualifikasi pendidikan pengawas menjadi penting untuk menyandang jabatan pengawas sekolah yang berkualitas dan profesional. ${ }^{18}$ Mengenai segala persyaratan kualifikasi pengawas sekolah, telah dijabarkan dalam Permendiknas No. 12 Tahun 2007, antara lain: ${ }^{19}$

a. Kualifikasi Pengawas Taman Kanak-kanak/RaudhatulAthfal (TK/RA) dan Sekolah Dasar/Madrasah Ibtidaiyah (SD/MI) adalah sebagai berikut:

1. Berpendidikan minimum sarjana (S1) atau diploma empat (D-IV) kependidikan dari perguruan tinggi terakreditasi.

2. a) Guru TK/RA bersertifikat pendidik sebagai guru TK/RA dengan pengalaman kerja minimum delapan tahun di TK/RA atau kepala sekolah TK/RA dengan pengalaman kerja minimum 4 tahun, untuk menjadi pengawas TK/RA.

b) Guru SD/MI bersertifikat pendidik sebagai guru SD/MI dengan pengalaman kerja minimum delapan tahun di SD/MI atau kepala sekolah SD/MI dengan pengalaman kerja minimum 4 tahun, untuk menjadi pengawas SD/MI.

3. Memiliki pangkat minimum penata, golongan ruang III/C.

4. Berusia setinggi-tingginya 50 tahun, sejak diangkat sebagai pengawas satuan pendidikan.

5. Memenuhi kompetensi sebagai pengawas satuan pendidikan yang dapat diperoleh melalui uji kompetensi dan atau pendidikan dan pelatihan fungsional pengawas, pada lembaga yang ditetapkan pemerintah.

6. Lulus seleksi pengawas satuan pendidikan.

b. Kualifikasi Pengawas Sekolah Menengah Pertama/Madrasah Tsanawiyah (SMP/MTs), Sekolah Menengah Atas/Madrasah Aliyah (SMA/MA), dan Sekolah Menengah Kejuruan/Madrasah Aliyah Kejuruan (SMK/MAK) adalah sebagai berikut:

1. Memiliki pendidikan minimum magister (S2) kependidikan dengan berbasis sarjana (S1) dalam rumpun mata pelajaran yang relevan pada perguruan tinggi terakreditasi.

\footnotetext{
${ }^{18}$ Ibid., 158.

19 BSNP, Peraturan Menteri Pendidikan Nasional Republik Indonesia No. 12 Tahun 2007 Tentang Standar Pengawas Sekolah/Madrasah (Jakarta: BSNP, 2007), 5-7.
} 
a) Guru SMP/MTs bersertifikat pendidik sebagai guru SMP/MTs dengan pengalaman kerja minimal delapan tahun dalam rumpun mata pelajaran yang relevan di SMP/MTs atau ke-pala sekolah SMP/MTs dengan pengalaman kerja minimum 4 tahun, untuk menjadi pengawas SMP/MTs sesuai dengan rumpun mata pelajarannya.

b) Guru SMA/MA bersertifikat pendidik sebagai guru dengan pengalaman kerja minimum delapan tahun dalam rumpun mata pelajaran yang relevan di SMK/MAK atau kepala sekolah SMK/MAK dengan pengalaman kerja minimum 4 Tahun, untuk menjadi pengawas SMK/MAK sesuai dengan rumpun mata pelajarannya.

2. Memiliki pangkat minimum penata, golongan ruang III/C.

3. Berusia setinggi-tingginya 50 tahun, sejak diangkat sebagai pengawas satuan pendidikan.

4. Memenuhi kompetensi sebagai pengawas satuan pendidikan yang dapat diperoleh melalui uji kompetensi dan atau pendidikan dan pelatihan fungsional pengawas, pada lembaga yang ditetapkan pemerintah.

5. Lulus seleksi pengawas satuan pendidikan.

Pada pendidikan khusus, Permendiknas tidak menyebutkan secara eksplisit mengenai Pengawas Pendidikan Khusus atau yang biasa kita ketahui bersama adalah Sekolah Luar Biasa (SLB). Menurut Syaiful Sagala, jika mengacu pada kualifikasi pengawas pada pendidikan dasar dan menengah, maka pengawas PLB (Pendidikan Luar Biasa) tentunya dipersyaratkan berpendidikan minimal S1 Kependidikan diutamakan dan S2 Kependidikan dalam rumpun mata pelajaran pendidikan khusus. Guru PLB haruslah bersertifikat dengan pengalaman kerja minimal 8 Tahun atau Kepala Sekolah PLB selama 4 Tahun. Dengan kualifikasi demikian, pengawas akan mempunyai kemampuan profesional yang lebih baik dibanding dengan guru yang dibinanya. ${ }^{20}$

Dengan persyaratan kualifikasi yang sedemikian ketat, harapannya adalah para pengawas bisa sangat profesional dalam melaksanakan tugasnya. Akan tetapi yang banyak terjadi, terutama di sekolah pedesaan adalah seperangkat kualifikasi ini hanyalah dijadikan sebagai alat formalitas untuk memperolah jabatan sebagai pengawas. Dalam prakteknya, banyak sekali yang tidak sesuai dengan SOP yang telah ditetapkan, terutama dalam supervisi pembelajaran atau akademik. Karena kebanyakan, para supervisor terlalu terfokus pada supervisi manajerial yang bersifat inspeksi.

\footnotetext{
${ }^{20}$ Sagala, Supervisi Pembelajaran, 159.
} 


\section{Kompetensi Pengawas Sekolah}

Kompetensi adalah seperangkat pengetahuan, keterampilan dan perilaku yang harus dimiliki, dikuasai dan dihayati oleh seseorang untuk dapat melakukan tugas-tugas profesionalnya. Oleh sebab itu, dalam merumuskan atau menetapkan kompetensi pengawas sekolah selain landasan filosofis, yuridis dan empiris juga memperhatikan: 1) konsep dasar pengawasan, 2) tugas pokok, fungsi dan tanggung jawabnya sebagai pengawas akademik dan pengawas manajerial, dan 3) profil pengawas saat ini dan kondisi ideal pengawas masa depan. ${ }^{21}$ Secara luas, dalam Permendiknas Nomor 12 Tahun 2007 dijelaskan kompetensi pengawas sekolah mulai dari tingkat kanak-kanak, sekolah dasar dan sekolah menengah. Agar tidak terlalu panjang, kompetensi pengawas ini ditulis secara global, karena pada intinya di tiap jenjang kompetensi tersebut sama.

Kompetensi Pengawas Taman Kanak-Kanak/Raudhatul Athfal (TK/RA), Sekolah Dasar/Madrasah Ibtidaiyah (SD/MI) dan Kompetensi Pengawas Sekolah Menengah Pertama/Madrasah Tsanawiyah (SMP/MTs) dan Pengawas Sekolah Menengah Atas/Madrasah Aliyah (SMA/MA) dalam Rumpun Mata Pelajaran yang Relevan (MIPA dan TIK, IPS, Bahasa, Olahraga Kesehatan, atau Seni Budaya) adalah sebagai berikut: ${ }^{22}$

\begin{tabular}{|c|c|c|}
\hline $\begin{array}{l}\mathrm{N} \\
\mathrm{o} .\end{array}$ & $\begin{array}{c}\text { Dimensi } \\
\text { kompetens } \\
\mathrm{i}\end{array}$ & Kompetensi utama \\
\hline \multirow{4}{*}{1.} & \multirow{4}{*}{$\begin{array}{l}\text { Kompetens } \\
\text { i } \\
\text { Kepribadia } \\
\text { n }\end{array}$} & $\begin{array}{l}\text { 1.1. Memiliki tanggung jawab sebagai pengawas satuan } \\
\text { pendidikan. }\end{array}$ \\
\hline & & $\begin{array}{l}\text { 1.2. Kreatif dalam bekerja dan memecahkan masalah, baik yang } \\
\text { berkaitan dengan kehidupan pribadinya maupun tugas-tugas } \\
\text { jabatannya. }\end{array}$ \\
\hline & & $\begin{array}{l}\text { 1.3. Memiliki rasa ingin tahu akan hal-hal baru tentang pen- } \\
\text { didikan dan ilmu pengetahuan, teknologi dan seni yang } \\
\text { menunjang tugas pokok dan tanggung jawabnya. }\end{array}$ \\
\hline & & $\begin{array}{l}\text { 1.4. } \begin{array}{l}\text { Menumbuhkan motivasi kerja pada dirinya dan pada } \\
\text { stakeholder pendidikan. }\end{array} \\
\end{array}$ \\
\hline \multirow{3}{*}{2.} & \multirow{3}{*}{$\begin{array}{l}\text { Kompetens } \\
\text { i Supervisi } \\
\text { Manajerial }\end{array}$} & $\begin{array}{l}\text { 1.1. Menguasai metode, teknik dan prinsip-prinsip supervisi dalam } \\
\text { rangka meningkatkan mutu pendidikan di sekolah menengah } \\
\text { yang sejenis. }\end{array}$ \\
\hline & & $\begin{array}{l}\text { 1.2. Menyusun program kepengawasan berdasarkan visi-misi- } \\
\text { tujuan dan program pendidikan sekolah menengah yang } \\
\text { sejenis. }\end{array}$ \\
\hline & & $\begin{array}{l}\text { 1.3. Menyusun metode kerja dan instrumen yang diperlukan untuk } \\
\text { melaksanakan tugas }\end{array}$ \\
\hline
\end{tabular}

${ }^{21}$ Ibid., 161.

${ }^{22}$ BSNP, Peraturan Menteri Pendidikan, 8-32. 


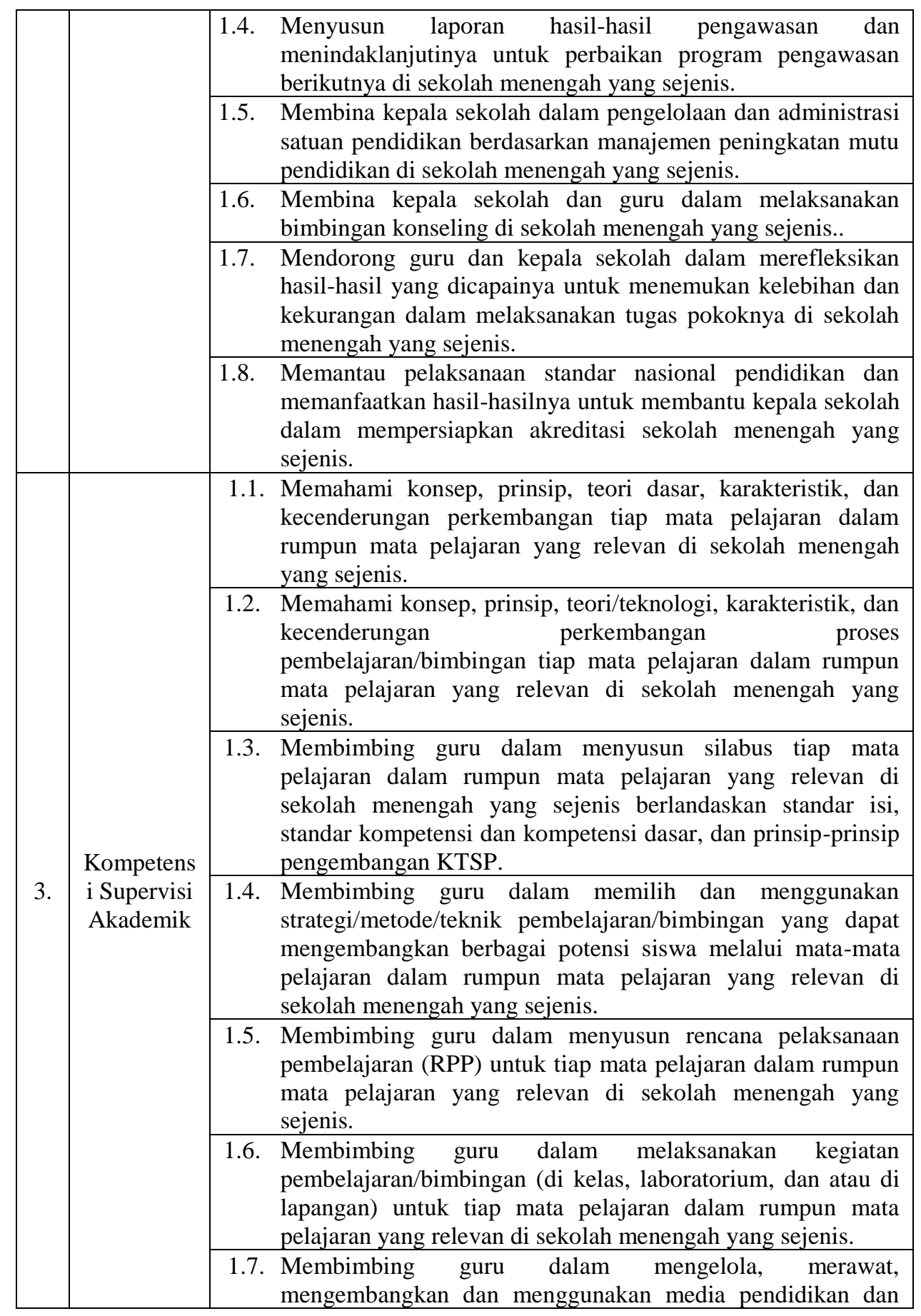




\begin{tabular}{|c|c|c|}
\hline & & $\begin{array}{l}\text { fasilitas pembelajaran/bimbingan tiap mata pelajaran dalam } \\
\text { rumpun mata pelajaran yang relevan di sekolah menengah } \\
\text { yang sejenis. }\end{array}$ \\
\hline & & $\begin{array}{l}\text { 1.8. Memotivasi guru untuk memanfaatkan teknologi informasi } \\
\text { dalam pembelajaran/bimbingan tiap mata pelajaran dalam } \\
\text { rumpun mata pelajaran yang relevan di sekolah menengah } \\
\text { yang sejenis. }\end{array}$ \\
\hline \multirow{6}{*}{4.} & \multirow{6}{*}{$\begin{array}{l}\text { Kompetens } \\
\text { i Evaluasi } \\
\text { Pendidikan }\end{array}$} & $\begin{array}{l}\text { 4.1. Menyusun kriteria dan indikator keberhasilan pendidikan dan } \\
\text { pembelajaran/bimbingan tiap mata pelajaran dalam rumpun } \\
\text { mata pelajaran yang relevan di sekolah menengah yang } \\
\text { sejenis. }\end{array}$ \\
\hline & & $\begin{array}{l}\text { 4.2. Membimbing guru dalam menentukan aspek-aspek yang } \\
\text { penting dinilai dalam pembelajaran/bimbingan tiap mata } \\
\text { pelajaran dalam rumpun mata pelajaran yang relevan di } \\
\text { sekolah menengah yang sejenis. }\end{array}$ \\
\hline & & $\begin{array}{l}\text { 4.3. Menilai kinerja kepala sekolah, kinerja guru dan staf sekolah } \\
\text { lainnya dalam melaksanakan tugas pokok dan tanggung } \\
\text { jawabnya untuk meningkatkan mutu pendidikan dan } \\
\text { pembelajaran/bimbingan pada tiap mata pelajaran dalam } \\
\text { rumpun mata pelajaran yang relevan di sekolah menengah } \\
\text { yang sejenis. }\end{array}$ \\
\hline & & $\begin{array}{l}\text { 4.4. Memantau pelaksanaan pembelajaran/ bimbingan dan hasil } \\
\text { belajar siswa serta menganalisisnya untuk perbaikan mutu } \\
\text { pembelajaran/bimbingan tiap mata pelajaran dalam rumpun } \\
\text { mata pelajaran yang relevan di sekolah menengah yang } \\
\text { sejenis. }\end{array}$ \\
\hline & & $\begin{array}{l}\text { 4.5. Membina guru dalam memanfaatkan hasil penilaian untuk } \\
\text { kepentingan pendidikan dan pembelajaran/bimbingan tiap } \\
\text { mata pelajaran dalam rumpun mata pelajaran yang relevan di } \\
\text { sekolah menengah yang sejenis. }\end{array}$ \\
\hline & & $\begin{array}{l}\text { 4.6. Mengolah dan menganalisis data hasil penilaian kinerja } \\
\text { kepala sekolah, kinerja guru dan staf sekolah di sekolah } \\
\text { menengah yang sejenis. }\end{array}$ \\
\hline \multirow{5}{*}{5.} & \multirow{5}{*}{$\begin{array}{l}\text { Kompetens } \\
\text { i Penelitian } \\
\text { Pengemba } \\
\text { ngan }\end{array}$} & $\begin{array}{l}\text { 5.1. Menguasai berbagai pendekatan, jenis, dan metode penelitian } \\
\text { dalam pendidikan. }\end{array}$ \\
\hline & & $\begin{array}{l}\text { 5.2. Menentukan masalah kepengawasan yang penting diteliti baik } \\
\text { untuk keperluan tugas pengawasan maupun untuk } \\
\text { pengembangan karirnya sebagai pengawas. }\end{array}$ \\
\hline & & $\begin{array}{l}\text { 5.3. Menyusun proposal penelitian pendidikan baik proposal } \\
\text { penelitian kualitatif maupun penelitian kuantitatif. }\end{array}$ \\
\hline & & $\begin{array}{l}\text { 5.4. Melaksanakan penelitian pendidikan untuk pemecahan } \\
\text { masalah pendidikan, dan perumusan kebijakan pendidikan } \\
\text { yang bermanfaat bagi tugas pokok tanggung jawabnya. }\end{array}$ \\
\hline & & $\begin{array}{l}\text { 5.5. Mengolah dan menganalisis data hasil penelitian pendidikan } \\
\text { baik data kualitatif maupun data kuantitatif. }\end{array}$ \\
\hline
\end{tabular}




\begin{tabular}{|c|c|c|}
\hline & & $\begin{array}{l}\text { 5.6. Menulis karya tulis ilmiah (KTI) dalam bidang pendidikan } \\
\text { dan atau bidang kepengawasan dan memanfaatkannya untuk } \\
\text { perbaikan mutu pendidikan. }\end{array}$ \\
\hline & & $\begin{array}{l}\text { 5.7. Menyusun pedoman/panduan dan atau buku/modul yang } \\
\text { diperlukan untuk melaksanakan tugas pengawasan di sekolah } \\
\text { menengah yang sejenis. }\end{array}$ \\
\hline & & $\begin{array}{l}\text { 5.8. Memberikan bimbingan kepada guru tentang penelitian } \\
\text { tindakan kelas, baik perencanaan maupun pelaksanaannya di } \\
\text { sekolah menengah yang sejenis. }\end{array}$ \\
\hline \multirow[t]{2}{*}{6.} & \multirow[t]{2}{*}{$\begin{array}{l}\text { Kompetens } \\
\text { i Sosial }\end{array}$} & $\begin{array}{l}\text { 5.1. Bekerja sama dengan berbagai pihak dalam rangka } \\
\text { meningkatkan kualitas diri untuk dapat melaksanakan tugas } \\
\text { dan tanggung jawabnya. }\end{array}$ \\
\hline & & 5.2. Aktif dalam kegiatan asosiasi pengawas satuan pendidikan. \\
\hline
\end{tabular}

Semua prasyarat ini sangat ideal untuk dimiliki oleh para pengawas. Akan sangat baik apabila semua persyaratan ini benar-benar dimiliki oleh semua pengawas sekolah di Indonesia. Selain itu, kualifikasi dan kompetensi benar-benar menjadi ruh yang menjiwai segala aktifitas pengawas dengan penuh integritas. Kemudian, dalam implementasinya harus ada kerja sama yang baik dari pihak sekolah yang disupervisi dengan pihak supervisor. Besarnya anggaran pendidikan sekarang, dengan adanya BOS atau bantuan lainnya juga perlu diwaspadai, karena dimana ada uang, maka di situ ada pula kesempatan untuk berlaku korup melalui deal-deal yang dilakukan di bawah meja.

\section{Kualifikasi Dan Kompetensi Guru}

Standar kualifikasi akademik dan kompetensi guru sangat diperhatikan oleh pemerintah. Hal ini adalah sebuah keharusan, karena bangsa yang besar adalah bangsa yang memiliki SDM mumpuni dan budi pekerti yang luhur dan pirantinya yang tiada lain kecuali melalui pendidikan. Bagaimana pendidikan akan menghasilkan anak-anak didik yang berkualitas, apabila guru-guru yang menjadi agen pembelajaran tidak kompeten dalam melakukan tugasnya. Untuk itulah, pemerintah sangat memperhatikan kompetensi guru ini dalam menjalankan tugasnya. Beberapa kebijakan telah dikeluarkan untuk mencetak para pendidik yang profesional. Hal ini tertuang dalam Undang-Undang RI No. 20 Tahun 2003 tentang Sistem Pendidikan Nasional, Undang-Undang RI No. 14 Tahun 2005 tentang Guru dan Dosen dan Peraturan Pemerintah No. 19 Tahun 2005 tentang Standar Pendidikan Nasional. Kemudian secara terperinci, kualifikasi dan kompetensi guru ini diperjelas mulai tingkat kanak-kanak, sekolah dasar dan menengah tertuang 
dalam Permendiknas, No. 16 Tahun 2007 tentang Standar Kualifikasi Akademik dan Kompetensi Guru. ${ }^{23}$

\section{Kualifikasi Guru ${ }^{24}$}

Kualifikasi akademik guru pada satuan pendidikan jalur formal mencakup kualifikasi akademik guru Pendidikan Anak Usia Dini/ Taman Kanak-kanak/Raudatul Athfal (PAUD/TK/RA), guru Sekolah Dasar/Madrasah Ibtidaiyah (SD/MI), guru Sekolah Menengah Pertama/Madrasah Tsanawiyah (SMP/MTs), guru Sekolah Menengah Atas/Madrasah Aliyah (SMA/MA), guru Sekolah Dasar Luar Biasa/Sekolah Menengah Luar Biasa/Sekolah Menengah Atas Luar Biasa (SDLB/SMPLB/SMALB), dan guru Sekolah Menengah Kejuruan/Madrasah Aliyah Kejuruan (SMK/MAK), sebagai berikut:

a. Kualifikasi Akademik Guru PAUD/TK/RA

Guru pada PAUD/TK/RA harus memiliki kualifikasi akademik pendidikan minimum diploma empat (D-IV) atau sarjana (S1) dalam bidang pendidikan anak usia dini atau psikologi yang diperoleh dari program studi yang terakreditasi.

b. Kualifikasi Akademik Guru SD/MI

Guru pada SD/MI, atau bentuk lain yang sederajat, harus memiliki kualifikasi akademik pendidikan minimum diploma empat (D-IV) atau sarjana (S1) dalam bidang pendidikan SD/MI (D-IV/S1 PGSD/PGMI) atau psikologi yang diperoleh dari program studi yang terakreditasi.

c. Kualifikasi Akademik Guru SMP/MTs

Guru pada SMP/MTs, atau bentuk lain yang sederajat, harus memiliki kualifikasi akademik pendidikan minimum diploma empat (D-IV) atau sarjana (S1) program studi yang sesuai dengan mata pelajaran yang diajarkan/diampu, dan diperoleh dari program studi yang terakreditasi.

d. Kualifikasi Akademik Guru SMA/MA

Guru pada SMA/MA, atau bentuk lain yang sederajat, harus memiliki kualifikasi akademik pendidikan minimum diploma empat (D-IV) atau sarjana (S1) program studi yang sesuai dengan mata pelajaran yang diajarkan/diampu, dan diperoleh dari program studi.

\section{Kompetensi Guru}

Standar kompetensi guru ini dikembangkan secara utuh dari empat kompetensi utama, yaitu kompetensi pedagogik, kepribadian, sosial, dan profesional. Keempat kompetensi tersebut terintegrasi dalam kinerja guru. Standar kompetensi guru mencakup kompetensi inti guru yang dikembangkan menjadi kompetensi guru PAUD/TK/RA, guru kelas SD/MI,

\footnotetext{
${ }^{23}$ Permendiknas No. 16 Tahun 2007 tentang Standar Kualifikasi Akademik dan Kompetensi Guru.

${ }^{24}$ Ibid., 3-4.
} 
dan guru mata pelajaran pada SD/MI, SMP/MTs, SMA/MA, dan SMK/MAK. ${ }^{25}$ Secara lebih jelas, Mulyana A.Z. memberikan penjabaran tentang empat kompetensi ini: ${ }^{26}$

a. Kompetensi Kepribadian

Kompetensi kepribadian merupakan kemampuan seseorang yang mencerminkan kepribadian yang mantap, stabil, dewasa, arif, berwibawa, menjadi teladan bagi peserta didik dan berakhlak mulia. Guru yang memiliki kompetensi ini pasti dapat melakukan tuntutan profesi dengan baik pula. Dia akan bangga menjadi guru dan memiliki konsistensi dalam bertindak sesuai dengan norma hukum, agama dan sosial serta memiliki etos kerja yang tinggi dalam menjalankan profesinya.

b. Kompetensi Pedagogik

Kemampuan pedagogik atau kemampuan mendidik sangat diperlukan guru dalam membimbing dan memberikan pembelajaran kepada siswa agar lebih terarah. Kompetensi pedagogik meliputi: 1) pemahaman terhadap peserta didik, 2) perancangan dan pelaksanaan pembelajaran, 3) Evaluasi hasil belajar dan 4) pengembangan peserta didik untuk mengaktualisasikan berbagai potensi yang dimilikinya.

c. Kompetensi Profesional

Kompetensi profesional merupakan penguasaan materi pembelajaran secara luas dan mendalam yang mencakup penguasaan materi sesuai kurikulum dan substansi keilmuan yang menaungi materinya, serta penguasaan terhadap struktur dan metodologi keilmuannya.

d. Kompetensi Sosial

Kompetensi sosial adalah kemampuan guru untuk dapat membangun komunikasi yang efektif dengan siswa, guru, kepala sekolah, wali murid, dan masyarakat secara umum.

\section{Supervisi Pembelajaran}

Dalam Buku Kerja Pengawas Sekolah, sangat jelas dibedakan antara supervisi manajerial dan supervisi akademik. Supervisi manajerial atau pengawasan manajerial merupakan fungsi supervisi yang berkenaan dengan aspek pengelolaan sekolah yang terkait langsung dengan peningkatan efisiensi dan efektivitas sekolah yang mencakup perencanaan, koordinasi, pelaksanaan, penilaian, pengembangan kompetensi sumber daya tenaga pendidik dan kependidikan. Sedangkan supervisi akademik atau supervisi pembelajaran adalah fungsi pengawas yang berkenaan dengan aspek pelaksanaan tugas pembinaan, pemantauan, penilaian dan pelatihan profesional guru dalam (1) merencanakan pembelajaran; (2) melaksanakan

\footnotetext{
${ }^{25}$ Ibid., 5.

${ }^{26}$ Mulyana A.Z., Rahasia Menjadi Guru Hebat; Memotivasi Diri Menjadi Guru Luar Biasa (Jakarta: Grasindo, 2010), 104-106.
} 
pembelajaran; (3) menilai hasil pembelajaran; (4) membimbing dan melatih peserta didik, dan (5) melaksanakan tugas tambahan yang melekat pada pelaksanaan kegiatan pokok sesuai dengan beban kerja guru. Hal tersebut dapat dilaksanakan melalui kegiatan tatap muka atau non tatap muka. ${ }^{27} \mathrm{Jadi}$, dapat diambil pengertian, bahwa supervisi pembelajaran merupakan pengawasan yang dilakukan pengawas atau kepala sekolah yang terfokus pada kegiatan pembelajaran yang dilakukan guru dan siswa sebagai ujung tombak keberhasilan pendidikan.

\section{Prinsip Supervisi Pembelajaran}

Dalam menjalankan tugasnya, supervisor harus memegang teguh beberapa prinsip yang menjadi pilar dalam proses pengawasan. Dalam hal ini, Prasojo dan Sudiono memaparkan beberapa prinsip dalam supervisi akademik atau pembelajaran, antara lain: ${ }^{28}$ Praktis, artinya mudah dikerjakan sesuai kondisi sekolah. Sistematis, artinya dikembangkan sesuai perencanaan program supervisi yang matang dan sesuai dengan tujuan pembelajaran. Obyektif, artinya masukan sesuai aspek-aspek instrument. Realistis, artinya berdasarkan kenyataan sebenarnya. Antisipatif, artinya mampu menghadapi masalah-masalah yang mungkin akan terjadi. Konstruktif, artinya mengembangkan kreativitas dan inovasi guru dalam mengembangkan proses pembelajaran. Kooperatif, artinya ada kerja sama yang baik antara supervisor dan guru dalam mengembangkan pembelajaran. Kekeluargaan, artinya mempertimbangkan saling asah, asih dan asuh dalam mengembangkan pembelajaran. Demokratis, artinya supervisor tidak boleh mendominasi pelaksanaan supervisi akademik. Aktif, artinya guru dan supervisor harus aktif berpartisipasi. Humanis, artinya mampu menciptakan hubungan kemanusiaan yang harmonis, terbuka, jujur, ajeg, sabar, antusias dan penuh humor. Berkesinambungan, artinya supervisi dilakukan secara teratur dan berkelanjutan oleh kepala sekolah. Terpadu, artinya menyatu dengan program pendidikan. Komprehensif, artinya memenuhi semua tujuan supervisi akademik.

\section{Tujuan dan Fungsi Supervisi Pembelajaran}

\section{A. Tujuan Umum}

Secara umum, tujuan supervisi pendidikan seperti yang diungkapkan Mukhtar dan Iskandar adalah untuk mengembangkan situasi pembelajaran yang lebih baik melalui pembinaan dan peningkatan profesi mengajar. Melalui supervisi pembelajaran, diharapkan kualitas pembelajaran yang dilakukan oleh guru semakin meningkat, dalam kemampuan, komitmen,

\footnotetext{
${ }^{27}$ Nana Sujana et al., Buku Kerja Pengawas Sekolah (Jakarta: Pusat Pengembangan Tenaga Kependidikan, Badan PSDM dan PMP Kementerian Pendidikan Nasional, 2011), 19-21.

${ }^{28}$ Lantip Dian Prasojo et al., Supervisi Pendidikan (Yogyakarta: Gava Media, 2011), 87-88.
} 
kemauan, dan motivasi yang dimiliki guru. ${ }^{29}$ Jadi, orientasi supervisi pembelajaran adalah pada terciptanya peningkatan profesionalisme guru dalam melakukan pembelajarannya secara terus-menerus.

\section{B. Tujuan Khusus}

Dalam mencapai tujuan umum di atas, terdapat pula tujuan khusus yang harus dicapai oleh pengawas dan guru. Luluk Nur Mufidah merinci tujuantujuan khusus pengawasan pendidikan dalam beberapa poin, antara lain: ${ }^{30}$

1) Membantu guru untuk lebih memahami tujuan sebenarnya dari pendidikan dan peranan sekolah dalam mencapai tujuan itu.

2) Membantu guru-guru untuk dapat lebih menyadari dan memahami kebutuhan dan kesulitan murid untuk menolong mereka mengatasinya.

3) Memperbesar kesanggupan guru-guru untuk melengkapi dan mempersiapkan murid-muridnya menjadi masyarakat yang efektif.

4) Membantu guru mengadakan diagnosa kritis terhadap aktivitas, kesulitan mengajar dan belajar muridnya dan menolong mereka melakukan perbaikan.

5) Memperbesar kesadaran guru-guru terhadap tata kerja yang demokratis, kooperatif dan memperbesar kesediaan untuk saling tolong-menolong.

6) Memperbesar ambisi guru untuk meningkatkan mutu karyanya secara maksimal dalam bidang keahliannya.

7) Membantu guru untuk dapat lebih memanfaatkan pengelamanpengalaman sendiri.

8) Membantu guru untuk dapat lebih mempopulerkan sekolah di masyarakat.

9) Melindungi guru apabila ada tuntutan tidak wajar dari masyarakat.

\section{Fungsi Supervisi Pembelajaran}

Dalam melaksanakan supervisi pembelajaran, ada beberapa hal yang bisa diungkap sekaligus menjadi fungsi pelaksanaan supervisi yang dilaksanakan. Sebagaimana yang dipaparkan oleh Mukhtar dan Iskandar, fungsi supervisi pembelajaran adalah: ${ }^{31}$

1) Dari pihak guru dapat diketahui kurang adanya semangat kerja, kesediaan bekerja dan berkumunikasi, kecakapan dalam melaksanakan tugas, menguasai metode mengajar, memahami tujuan dan program kerja, kurang mentaati peraturan ketertiban dan lain sebagainya.

2) Dari pihak siswa/peserta didik dapat diketahui kurang adanya kerajinan dan ketekunan peserta didik, mentaati peraturan, keinsyafan tentang perlunya belajar guna mempersiapkan diri bagi kebutuhan masa depan dan sebagainya.

\footnotetext{
${ }^{29}$ Mukhtar et al., Orientasi Baru Supervisi Pendidikan (Jakarta: GP Press, 2009), 53.

${ }^{30}$ Luluk Nur Mufidah, Supervisi Pendidikan (Yogyakarta: Teras, 2009), 18-19.

${ }^{31}$ Mukhtar et al., Orientasi Baru, 53-54.
} 
3) Dari sisi prasarana, dapat diketahui kurang terpenuhinya syarat-syarat tentang gedung, halaman, kesehatan, keamanan dan lain sebagainya termasuk kurang tersedianya alat-alat pelajaran, seperti bangku, kursi, lemari, papan tulis, buku-buku pelajaran dan lain sebagainya.

4) Dari pihak kepala sekolah, dapat diketahui kurang adanya tanggung jawab pengabdian, kewibawaan, pengetahuan, dan sebagainya. Bahkan juga dapat berguna untuk mengetahui bagaimana gaya kepemimpinan kepala sekolah.

\section{Teknik-Teknik Supervisi Pembelajaran}

Dalam menjalankan tujuan dan fungsi supervisi pembelajaran, sangat perlu bagi supervisor untuk mengetahui macam-macam bentuk pelayanan atau teknik-teknik supervisi yang bisa dilakukan. Berbagai macam teknik ini dapat digunakan sesuai dengan sasaran atau tujuan apa yang diinginkan secara spesifik. Dalam hal ini, Binti Maunah memberikan paparan tentang berbagai bentuk pelayanan yang bisa diberikan supervisor dalam melakukan tugasnya, antara lain sebagai berikut: ${ }^{32}$

1. Membantu guru dalam memilih dan mengorganisir bahan-bahan pelajaran. Bentuk kegiatannya antara lain:

a) Pembinaan kurikulum.

b) Membantu guru-guru mengidentifikasi tujuan pengajaran.

c) Membantu guru-guru dalam menggali dan mengembangkan bahan pelajaran.

d) Membantu guru-guru memilih textbooks.

e) Membantu guru mempelajari murid-murid dan kebutuhan mereka.

f) Personalia dan organisasi penyusunan bahan pelajaran.

g) Macam-macam inservice action, meliputi penempatan guru baru, penyegaran para guru di awal atau akhir tahun, workshop, keperluan konsultasi dan pembinaan pengelolaan perpustakaan.

2. Membantu guru-guru menyesuaikan pengajaran dengan perbedaan individual. Bentuk kegiatannya antara lain:

a) Membantu para

b) guru menyadari adanya perbedaan diantara para murid.

c) Mengembangkan cara-cara pemecahan masalah-masalah perbedaan individual.

d) Penggunaan pelajaran diagnostic dan remedial untuk memecahkan masalah-masalah perbedaan individual.

e) Membantu guru-guru dalam pengajaran kelompok-kelompok homogen.

3. Membina bimbingan belajar murid-murid. Bentuk kegiatannya:

32 Binti Maunah, Supervisi Pendidikan Islam; Teori dan Praktik, (Yogyakarta: Teras, 2009), 215-238. 
a) Membina bimbingan belajar murid-murid.

b) Mendiagnosa permasalahan murid dalam belajar.

c) Membantu guru-guru dalam mengembangkan kebiasaan belajar yang tepat.

d) Pembinaan perpustakaan dan penggunaannya untuk belajar.

4. Membina partisipasi guru-guru dalam aktivitasnya melayani para murid. Bentuknya antara lain:

a) Pembinaan guru dalam membimbing kegiatan ekstrakurikuler.

b) Membina pelayanan-pelayanan guidance (bantuan kepada muridmurid hingga mereka mampu mengontrol tingkah laku mereka sendiri) untuk guru-guru.

c) Membina guru-guru dalam pengelolaan kelas-kelas.

d) Membina guru-guru dalam pergaulan profesional mereka.

5. Membantu guru-guru yang mengalami masalah secara individual.

\section{Implementasi Tugas Pokok dan Fungsi Supervisor dalam Melakukan Peningkatan Mutu Pembelajaran di SMP Ar-Rohmah Dau Malang}

SMP Ar-Romah Malang adalah sekolah di bawah naungan Dinas Pendidikan Kabupaten Malang, hanya saja muatan pendidikan agama Islam ada penambahan porsi pembelajarannya. Membahas implementasi supervisi atau proses pengawasan di SMP Ar-Rohmah ini, penulis telah berwawancara cukup mendalam dengan wakil kepala sekolah, Bapak Suwanto, S.Pd. dan Bapak Kepala Sekolah, Bapak Syarif Hidayatullah, S.Sos.I. Sesuai penjelasan Bapak Suwanto, SMP Ar-Rohmah lebih mengandalkan pengawasan internal di dalam sekolah. Karena sekolah telah memiliki SOP (Standard Operational Procedure) atau sistem yang sangat kompleks. Kehadiran pengawas eksternal, baik dari Diknas ataupun Kemenag tidak berpengaruh terlalu signifikan pada kinerja guru. Hal itu dikarenakan intensitas pembinaan pengawas yang sedikit dan lebih cenderungnya pengawas hanya melakukan monitoring administratif saja. Dalam menanggulangi hal ini, pengawasan internal kepala sekolah menjadi ujung tombak peningkatan kinerja para guru di sini. Seperti yang dikatakan Bapak Suwanto:

Adapun teknik yang menjadi andalan kami dalam meningkatkan kinerja guru dan karyawan serta meningkatkan prestasi siswa adalah dengan adanya rapat evaluasi pada tiap hari Sabtu. Pada rapat evaluasi besar ini, ada banyak sekali yang dibahas, mulai konteks seluruh yayasan sampai pada masalah tiap bidang studi. ${ }^{33}$

\footnotetext{
${ }^{33}$ Suwanto, Wawancara (Di ruang rapat kantor SMP Ar-Rohmah "Boarding School", Kamis 20 Maret 2014, 08.00 - 10.00 WIB).
} 
Bapak Suwanto, S.Pd. adalah wakil kepala sekolah yang juga mengurusi kurikulum di SMP Ar-Rohmah ini. Terkait dengan permasalahan pembelajaran para guru, beliau yang secara teknis sangat mengetahui bagaimana keadaannya.

Pengawas datang ke SMP Ar-Rohmah ini tidak berkala atau rutin tiap bulan, tiap semester atau dalam jangka waktu tertentu. Akan tetapi mereka baru memberikan kabar ketika baru akan melakukan monitoring atau pengawasan. Dalam penjelasannya, Bapak Syarif Hidayatullah menyatakan:

Para pengawas datang ke SMP Ar-Rohmah tidak secara rutin. Mereka datang tergantung kebutuhan pengawas itu sendiri. Para pengawas memiliki area tanggung jawab sendiri-sendiri, di mana mereka melakukan pengawasan pada sekolah-sekolah yang hanya menjadi tanggung jawabnya. Hanya saja, mungkin jumlah pengawasnya yang terlalu sedikit, sehingga pengawas tidak bisa datang mengawasi secara rutin. ${ }^{34}$

Banyak sekali pengawas yang telah datang silih berganti di SMP ini, mungkin itu dikarenakan terlalu sering adanya pergantian personil. Akan tetapi, pengawas yang terakhir datang ke SMP Ar-Rohmah ini bisa disebutkan adalah Bapak Zainuri, M.Pd.I. yang merupakan pengawas PAI dari Kantor Kemenag Kabupaten Malang dan Ibu Siti Umasitah, M.Pd. yang merupakan pengawas dari Dinas Pendidikan Kabupaten Malang. Pengawasan yang dilakukan Bapak Zainuri, lebih difokuskan pada para guru PAI yang telah memperoleh sertifikasi. Sesekali waktu beliau meminta masuk ke dalam kelas untuk melihat pembelajaran para guru, akan tetapi lebih banyak melakukan pengawasan di kantor dan secara langsung memonitoring perangkat pembelajaran para guru PAI. Sedangkan Ibu Siti Umasitah sebagai pengawas dari Diknas lebih banyak melakukan pengawasan manajerial. Adapun yang dimonitor dan diberi bimbingan adalah terkait dengan kondisi siswa, prestasi mereka, sarana prasarana, kegiatan kurikulum dan kesiswaan.

Menurut paparan Bapak Suwanto, para pengawas ini berperilaku sangat baik ketika berada di SMP Ar-Rohmah. Tidak pernah ada inspeksi mendadak kemudian para guru atau pegawai dimarahi, akan tetapi mereka berkomunikasi dengan santun, kalaupun ada kesalahan, mereka menegur kepala sekolah dengan bahasa yang halus. Di samping itu, jujur dipaparkan bahwa tidak pernah ada suap-menyuap di SMP Ar-Rohmah ini. Beliau menegaskan;

Perlu saya tambahkan, bahwa dari pihak sekolah tidak pernah memberikan uang semacam suap kepada para pengawas. Begitupun

\footnotetext{
${ }^{34}$ Syarif Hidayatullah, Wawancara (Di ruang tamu kantor SMP Ar-Rohmah "Boarding School”, Senin 24 Maret 2014, 09.00 - 11.00 WIB).
} 
juga pengawas, tidak pernah meminta upeti apapun kepada kami. Hanya saja, para pengawas cenderung pasif dalam membina para guru di sini. ${ }^{35}$

Jadi, tidak ada suap-menyuap di sini, terkait permintaan angka prestasi sekolah di SMP ini dan lain sebagainya. Akan tetapi, terdapat kesamaan informasi dari Kepala SMP dan wakilnya, bahwa dalam memberikan pembinaan, para pengawas ini kurang aktif untuk memberikan pembinaan dan arahan, terutama untuk para guru. Apabila ada permintaan dari pihak SMP Ar-Rohmah, baru kemudian pengawas merespon untuk datang, akan tetapi semua biaya pembinaan atau pelatihan tetap ditanggung oleh pihak sekolah.

\section{Implementasi Tugas Pokok dan Fungsi Guru dalam Melakukan} Peningkatan Mutu Pembelajaran di SMP Ar-Rohmah Dau Malang

Dalam meningkatkan kualitas pembelajaran para guru, SMP ArRohmah sudah menyiapkan sistem yang sangat baik dan canggih. Ini dilakukan dalam rangka menindak lanjuti segala pembinaan atau pelatihan yang dilakukan beserta para pengawas. Sistem pengawasan internal yang dilakukan kepala sekolah adalah: 1) rapat evaluasi mingguan setiap hari Sabtu, 2) penyetoran perangkat pembelajaran secara digital setiap tahun dan bulannya dan 3) pemberian reward dan punishment bagi para guru.

Rapat mingguan dilakukan pada hari Sabtu mulai jam 08.00 WIB sampai dengan jam 11.00 WIB. Dalam rapat ini ada 3 sesi, sesi pertama adalah rapat yayasan, sesi kedua adalah rapat tiap unit lembaga dan sesi ke tiga adalah Rapat Guru Bidang Studi (RGBS). Sesi pertama berisi evaluasi menyeluruh kegiatan yayasan dan proyeksi kegiatan ke depan yang akan dilakukan. Pada sesi ke dua, semua berpindah dan mengelompok sesuai unit lembaga masing-masing, yaitu SMP, SMA dan Pesantren, di sana dilakukan evaluasi penyeluruh terhadap semua komponen unit lembaga. Baru kemudian pada sesi ke tiga, guru berkumpul sesuai dengan bidang studinya yang diketuai oleh ketua RGBS. Di sana dilakukan evaluasi secara mendalam terkait dengan prestasi siswa, kendala-kendala dalam mengajar, kesulitan siswa dan sebagainya. Semua keputusan hasil rapat didokumentasikan tertulis untuk dilaporkan kepada kepala sekolah.

Pengawasan pembelajaran dilakukan oleh bagian kurikulum yang berkoordinasi dengan kepala sekolah dilakukan secara online dalam bentuk digital. Pada tiap awal tahun pelajaran, para guru diwajibkan untuk menyusun perangkat pembelajaran yang meliputi Program Tahunan (PROTA), Program Semester (PROSEM), Rincian Pekan Efektif (RPE). Silabus dan lain-lain. Sedangkan Rancangan Pelaksanaan Pembelajaran

\footnotetext{
${ }^{35}$ Suwanto, Wawancara (Kamis 20 Maret 2014).
}

El-Banat Vol. 9. No.1, Januari-Juni 201955 
(RPP) diserahkan setiap bulan. Sebagaimana yang dikatakan Bapak Arif Asy'ari, S.Pd.I. (salah seorang guru SMP Ar-Rohmah):

Mengenai perangkat pembelajaran, para guru diwajibkan menyerahkan semuanya di awal tahun pelajaran sebelum proses KBM dimulai. Itu sebagai tanda bahwa guru telah mengonsep pembelajarannya dalam setahun dengan matang. Selain itu, diperkuat lagi dengan setiap bulannya juga diharuskan untuk menyerahkan perangkat pembelajaran yang akan di gunakan pada pembelajaran. Semua itu dibuat dalam bentuk hard copy dan soft copy. ${ }^{36}$

Semuanya harus lengkap dan disiapkan dalam bentuk file maupun hard copy. Sekolah memiliki sistem komputerisasi yang sudah canggih, layaknya perguruan tinggi. Setiap guru memiliki kode akses website sekolah sendiri-sendiri. Apabila sudah tiba waktunya pengumpulan perangkat pembelajaran, maka tiap guru harus meng-upload-nya di website sekolah. Kemudian dikoreksi oleh bagian kurikulum, dalam hal ini adalah Bapak Suwanto, S.Pd. Apabila ada guru yang belum menyetorkan perangkatnya, maka sanksi yang diberlakukan adalah penahanan gaji bulanan, sampai perangkatnya selesai diunggah. Sebaliknya, bagi guru yang mengunggah perangkatnya tepat waktu, maka dia akan mendapatkan reward dari sekolah berupa pemberian bahan makanan pokok rumah tangga secara berkala tiap bulan. Itu dilakukan dalam rangka memacu semangat para guru untuk melakukan persiapan yang matang sebelum mengajar.

Apabila pelanggaran dilakukan oleh guru, maka sekolah melakukan langkah-langkah yang diperlukan. Hal itu dilakukan kepala sekolah, karena yang diatur di sini adalah manusia, maka seketat apapun aturan yang dicanangkan, pasti ada saja beberapa oknum yang masih melanggarnya. Seperti paparannya:

Walaupun peraturan sudah sedemikian ketat, tetap ada saja guru yang melanggar. Biasanya saya memberikan teguran, setelah diberikan teguran, saya serahkan sepenuhnya kepada guru tersebut. Menghadapi guru dan karyawan yang bermacam-macam, membutuhkan banyak teknik dan kesabaran. Saya sangat menyadari, manusia punya kecenderungan naik turun dalam semangat bekerja. ${ }^{37}$

Ada beberapa hal yang dilakukan kepala sekolah, pertama adalah teguran untuk perbaikan, kemudian seperti yang disebut di atas adalah penahanan gaji bulanan dan apabila pelanggaran itu sudah sangat parah, maka guru bisa dikeluarkan. Sekolah sangat menaati SOP (Standard

\footnotetext{
${ }^{36}$ Arif Asy'ari, Wawancara (Di salah satu warung makan Desa Dadaprejo, Rabu 19 Maret 2014, 21.00 - 22.00 WIB).

${ }^{37}$ Syarif Hidayatullah, Wawancara (Senin 24 Maret 2014).
} 
Operational Procedure) yang telah ditentukan dan tidak merasa segan kalau memang harus mengeluarkan salah seorang guru karena pelanggaran yang dilakukan. Tentunya semua itu dilakukan dengan sangat menjunjung tinggi etika kemanusiaan, kepala sekolah menegur dengan halus dan urutan teguran yang telah disebutkan.

\section{Kerja Sama antara Supervisor dan Guru dalam Meningkatkan Mutu Pembelajaran siswa di SMP Ar-Rohmah Dau Malang}

Kerja sama antara supervisor dan pihak sekolah dalam hal ini guru, sering dilakukan, walaupun tidak terlalu intensif. Ada dua macam kerja sama, sesuai keterangan dari Bapak Suwanto dan Bapak Syarif Hidayatullah, yaitu pembinan yang merupakan program dari pengawas sendiri dan program pembinaan yang memang permintaan dari sekolah dengan melibatkan juga pengawas di dalamnya. Program pembinaan dari pengawas, sebagaimana yang pernah dilakukan antara lain; pelatihan kurikulum 2013, pelatihan pengurus perpustakaan dan monitoring administrasi sekolah. Semuanya dilakukan di luar sekolah, biasanya bertempat di kantor dinas pendidikan atau di salah satu sekolah yang ditunjuk untuk kegiatan tersebut. Kegiatan yang rutin dilakukan adalah monitoring administrasi yang kolektif dilakukan serentak beberapa sekolah dalam satu rayon.

Program pembinaan dilakukan pula oleh internal SMP Ar-Rohmah, dengan bekerja sama dengan pengawas. Seperti yang dikatakan Bapak Suwanto:

Pembinaan di dalam sekolah lebih banyak diinisiasi oleh sekolah sendiri yang kemudian melibatkan pengawas/supervisor. Supervisor pun dengan senang hati turut hadir dalam acara yang diinisiasi sekolah tersebut, walaupun dalam tugas dinasnya tidak terjadwal secara resmi. ${ }^{38}$

Adapun program pembinaan yang merupakan inisiatif dari sekolah sendiri adalah: workshop kurikulum 2013, bedah SKL (Standar Kompetesi Lulusan) dan workshop metodologi pembelajaran. Dalam kegiatan tersebut, sekolah bekerja sama dengan pengawas, dengan mendatangkan ahli pendidikan dari Universitas Negeri Malang (UM). Semua biaya penyelenggaraan ditanggung oleh sekolah. Harapan dari kegiatan ini adalah untuk lebih meningkatkan kualitas pembelajaran guru secara internal di SMP Ar-Rohmah ini. Kegiatan-kegiatan ini dilakukan secara berkala oleh pihak sekolah, dengan perencanaan yang matang terlebih dahulu.

\section{Analisis Data}

\section{A. Analisis Strength (Kekuatan)}

1. Sistem pengawasan internal yang sangat baik dan canggih di SMP ArRohmah ini menjadikan sebuah potensi yang sangat besar bagi

\footnotetext{
${ }^{38}$ Suwanto, Wawancara (20 Maret 2014).
} 
pengembangan pembelajaran di SMP ini. Apabila para guru dengan ditambah para karyawannya dapat mengikuti SOP ini dengan baik dan benar-benar mau untuk meningkatkan profesionalismenya, maka beberapa tahun ke depan sekolah ini akan bisa menjadi sekolah percontohan dengan SDM guru yang baik dan sistem pengawasan yang sempurna.

2. Dukungan dana yang besar dimiliki oleh SMP ini. Sebagai sekolah yang lahir dari Ormas Hidayatullah yang mana sudah memiliki jaringan nasional, bahkan internasional, maka akan banyak sekali sumber dana yang diperoleh dalam rangka meningkatkan kualitas pendidikan di SMP ini. Sumber ke dua adalah dana dari para donatur dan wali murid yang apabila dikalkulasi jumlahnya sangat besar. Ini terbukti dengan cepatnya pengembangan gedung sekolah yang dimiliki dan banyaknya kegiatan pelatihan yang diadakan oleh sekolah secara mandiri.

3. SMP Ar-Rohmah tidak tergantung pada pembinaan dari pengawas eksternal saja. Tetapi sekolah telah mampu menciptakan sistem yang baik dan berjalan dengan seksama yang secara terus-menerus ditingkatkan.

\section{B. Weaknesses (Kelemahan)}

1. Pengawas eksternal kurang aktif dalam memberikan analisis kekurangan sekolah ataupun pembinaan kepada para guru. Kepasifan pengawas ini cukup menyulitkan sekolah ketika akan mengambil tindakan kebijakan yang strategis untuk meningkatkan kinerja para gurunya.

2. Perekrutan SDM guru di SMP ini tidak terlalu mementingkan ijazah pendidikan, tetapi semua disiplin ilmu dalam jenjang S1. Walaupun tidak jurusan pendidikan, apabila keilmuannya sudah cukup, menurut sekolah, itu bisa dikembangkan sendiri. Sekolah bisa mengalami kesulitan, karena guru yang belajar pada ilmu murni saja mungkin kurang terampil dalam kompetensi pembelajaran. Keadaan itu menjadikan sekolah harus senantiasa mengadakan pelatihan pembelajaran terus-menerus.

3. Para guru yang kurang berkomitmen dan integritasnya kurang kuat akan sering keluar dari sekolah dan mencari sekolah lain. Ini sering sekali terjadi, akibatnya siswa yang menjadi korban karena terlalu sering ada pergantian tenaga pengajar. Di mana siswa harus banyak menyesuaikan diri dengan guru barunya.

\section{Opportunities (Peluang)}

1. Supervisor/pengawas yang mendukung apabila diajak bekerja sama dengan pihak sekolah dalam rangka meningkatkan kualitas 
pembelajaran, walaupun hanya bersifat pasif. Dengan demikian, program dari sekolah akan dengan mudah dapat terealisasi.

2. Perangkat sistem SOP (Standar Operational Procedure) yang sudah mapan dimiliki oleh SMP Ar-Rohmah ini. Dengan demikian, sekolah tidak perlu susah menyusun aturan macam-macam lagi, akan tetapi hanya perlu fokus pada penerapan seluruh aturan yang ada itu.

3. Dengan pengembangan bahasa Inggris di SMP ini, ke depannya SMP ini bisa menjadi sekolah yang bertaraf internasional.

D. Threats (Hambatan)

1. Supervisor kurang aktif dalam berinisiatif untuk mengadakan bimbingan sendiri dengan analisis yang dia miliki terkait dengan kekurangan apa saja dalam pembelajaran yang harus ditingkatkan di SMP Ar-Rohmah.

2. Para guru eks guru SMP Ar-Rohmah yang dikeluarkan atau keluar sendiri dari lembaga ini banyak memberikan informasi negatif kepada masyarakat terkait pendidikan di SMP Ar-Rohmah. Hal ini dapat menyebabkan masyarakat berpenilaian negatif terhadap lembaga dan itu akan dapat mempengaruhi kuantitas penerimaan siswa di SMP ini.

3. Beberapa oknum guru ada yang masih melanggar SOP yang telah ditetapkan, apabila ini terus-menerus terjadi, maka penyakit ini dapat menular kepada guru-guru yang lainnya.

\section{Penutup}

Supervisor/pengawas kurang sungguh-sungguh dalam memberikan pembinaan secara aktif kepada guru di SMP Ar-Rohmah ini. Di sisi lain, dengan kemampuan yang dimiliki, analisis yang tajam dari pengawas ini sangat diperlukan untuk penyempurnaan dan perbaikan pembelajaran.

Mayoritas guru di SMP Ar-Rohmah ini melakukan pembelajaran dengan baik dan mematuhi semua SOP yang telah ditetapkan di sekolah. Walaupun penguasaan metode pembelajaran kurang, mereka sangat antusias untuk belajar berinovasi dalam melakukan pembelajaran di kelas. Sedangkan guru yang masih lemah hanya sebagian kecil saja dan itu dikarenakan kurang adanya integritas dan komitmen dari dalam diri mereka sendiri.

Kerja sama antara guru dan pengawas lebih banyak dilakukan di dalam sekolah yang diinisiasi oleh sekolah sendiri. SMP Ar-Rohmah lebih berperan aktif dari pada pembinaan oleh pengawas/supervisor eksternal. Pembinaan di dalam sekolah lebih banyak memberikan pengaruh dari pada pembinaan di luar sekolah dalam rangka meningkatkan mutu pembelajaran para guru SMP Ar-Rohmah ini.

Saran

Supervisor/pengawas eksternal hendaknya melakukan pembinaan secara aktif kepada tiap sekolah yang menjadi tanggung jawabnya, bukan 
secara pasif. Artinya, secara aktif mendiagnosa kekurangan ataupun kesalahan apa saja yang dilakukan oleh sekolah yang terkait dengan pembelajaran, untuk kemudian diberikan tindak penanganan yang sesuai dengan masing-masing kekurangan itu. Karena dengan kualifikasi dan kompetensi yang dimiliki, analisa yang dilakukan supervisor eksternal tentunya lebih dalam dan tepat dari pada hasil analisa yang dilakukan kepala sekolah. Apabila keduanya dipadukan secara kolaboratif, maka akan sangat baik dalam pengembangan pembelajaran di SMP Ar-Rohmah ke depan.

Para guru SMP Ar-Rohmah hendaknya mengaplikasikan SOP (Standar Operational Procedure) yang telah dicanangkan ini dengan profesionalitas yang tinggi dana rasa keikhlasan yang besar dalam rangka meningkatkan kompetensi dan profesionalitas keahlian dalam bidang belajar mengajar untuk dirinya masing-masing, bukan hanya sekedar hadir untuk mengajar sebagai tuntutan bekerja belaka. Jika dalam diri masing-masing guru tertanam semangat yang demikian, maka SMP Ar-Rohmah akan menjadi sekolah teladan melalui guru-guru terampil yang dimilikinya.

Kerja sama harus dilakukan secara intensif antara pengawas/supervisor dengan semua kepala sekolah pada rayon yang menjadi tanggung jawab pengawasan supervisor untuk kemudian diadakan pembinaan. Apabila permasalahan yang dialami sama antar beberapa sekolah, pembinaan bisa dilakukan secara kolektif melalui workshop. Kemudian jika permasalahan yang ada spesifik hanya pada satu sekolah, maka pembinaan dilakukan di internal sekolah yang bersangkutan. Untuk mengetahui permasalahan pada tiap sekolah, harus ada keterbukaan dari pihak sekolah kepada pengawas, sebaliknya pengawas juga tidak boleh memberikan intervensi kepada sekolah yang dibinanya apabila ada temuan buruk dari inspeksi yang dilakukan. Jika komunikasi seperti ini terbentuk, maka masalah buruknya kualitas pembelajaran di tiap sekolah akan teratasi.

\section{Daftar Rujukan}

Ahmadi, Rulam. Memahami Metodologi Penelitian Kualitatif. Malang: UM Press 2005.

Asy'ari, Arif. Wawancara (Di salah satu warung makan Desa Dadaprejo, Rabu 19 Maret 2014, 21.00 - 22.00 WIB).

Bogdan, Robert C. et al., Kualitatif Dasar-dasar Penelitian, terj. A. Khozin Afandi. Surabaya: Usaha Nasional, 1993.

BSNP, Peraturan Menteri Pendidikan Nasional Republik Indonesia No. 12 Tahun 2007 Tentang Standar Pengawas Sekolah/Madrasah. Jakarta: BSNP, 2007.

Bull, Victoria (ed.). Oxford; Learner's Pocket Dictionary. New York: Oxford University Press, 2008.

Bungin, M. Burhan. Penelitian Kualitatif. Jakarta: Kencana, 2007. 
Enchols, John M. et al., Kamus Inggris Indonesia; An English-Indonesian Dictionary. Jakarta: Gramedia, 1996.

Hidayatullah, Syarif. Wawancara (Di ruang tamu kantor SMP Ar-Rohmah "Boarding School", Senin 24 Maret 2014, 09.00 - 11.00 WIB).

Maunah, Binti. Supervisi Pendidikan Islam; Teori dan Praktik. Yogyakarta: Teras, 2009.

Moeloeng, Lexy J. Metodologi Penelitian Kualitatif. Bandung: Remaja Rosdakarya, 2007.

Mufidah, Luluk Nur. Supervisi Pendidikan. Yogyakarta: Teras, 2009.

Mukhtar et al., Orientasi Baru Supervisi Pendidikan. Jakarta: GP Press, 2009.

Muslim, Sri Banun. Supervisi Pendidikan Meningkatkan Kualitas Profesionalisme Guru. Bandung: Alfabetaa, 2009.

Permendiknas No. 16 Tahun 2007 tentang Standar Kualifikasi Akademik dan Kompetensi Guru.

Pidarta, Made. Supervisi Pendidikan Kontekstual. Jakarta: Rineka Cipta, 2009.

Prasojo, Lantip Dian. et al., Supervisi Pendidikan. Yogyakarta: Gava Media, 2011.

Sagala, Syaiful. Supervisi Pembelajaran dalam Profesi Pendidikan. Bandung: Alfabeta, 2010.

Sahertian, Piet A. Konsep Dasar \& Teknik Supervisi Pendidikan; Dalam Rangka Pengembangan SumberDaya Manusia. Jakarta: Rineka Cipta, 2000.

Sujana, Nana. et al., Buku Kerja Pengawas Sekolah. Jakarta: Pusat Pengembangan Tenaga Kependidikan, Badan PSDM dan PMP Kementerian Pendidikan Nasional, 2011.

Suryabrata, Sumardi. Metodologi Penelitian. Jakarta: Raja Grafindo, 1998.

Sutarsih, Cicih. et al., "Supervisi Pendidikan", Tim Dosen Administrasi Pendidikan UPI, Manajemen Pendidikan. Bandung: Alfabeta, 2008.

Suwanto, Wawancara (Di ruang rapat kantor SMP Ar-Rohmah "Boarding School", Kamis 20 Maret 2014, 08.00 - 10.00 WIB).

Suwanto, Wawancara (Kamis 20 Maret 2014).

Z., Mulyana A. Rahasia Menjadi Guru Hebat; Memotivasi Diri Menjadi Guru Luar Biasa. Jakarta: Grasindo, 2010. 